\title{
Peningkatan Produksi, Pencatatan Kartu Persediaan Dan Pemasaran Sale Pisang UD Sumber Alam Buana di Kabupaten Banyuwangi
}

\author{
Dilla Cattleyana1, Adytira Rachman². \\ Universitas 17 Agustus 1945 Banyuwangi \\ Email: 1dillacattleyana52@gmail.com, 2 Aditiraa@gmail.com
}

\begin{abstract}
Micro, Small and Medium Enterprises (UMKM) has an important role in the Indonesian economy, one of which can help the per capita income of the Indonesian state, especially in Banyuwangi Regency, as well as in the UM Banana Sale UD UD. Sumber Alam Buana, located at the eastern end of the island of Java, precisely in Banyuwangi. The UMKM is one of Banyuwangi's original typical food businesses from Ambon banana raw material, bearing in mind that typical food is identical to souvenirs (souvenirs) when visiting Banyuwangi, certainly not forgetting to bring and share them with you. However, there are problems in the field of production of UD Banana Banana $U D$, namely the low production capacity of processing banana raw materials because it still uses a cutting knife and the appropriate method has not been applied to record raw materials or finished goods so that the owner is less able to control the cycle of raw materials or finished goods. While in the marketing sector it is still conventional to be entrusted in a gift shop so that it can only wait for whether the product is sold or vice versa. The solution to the development activities of UMKM Sale Banana UD Sumber Alam Buana includes counseling and training using a banana chopper tool that is more efficient than a knife that has been used to chop banana raw materials. Whereas in terms of recording to help partners to control raw material inventory and finished goods efficiently and effectively, the need for training knowledge and assistance to owners and employees using a perpetual method stock card (inventory). To expand market share that has demanded the use of technology, training is held to make e-mail as a portal to access several e-commerce websites and to open online stores through social media such as Facebook and others. The results achieved in the Community Service program are the development of this business in terms of increasing production capacity, managing raw materials, expanding markets and increasing income.
\end{abstract}

Keywords: Production, Inventory, and Marketing Card Recording 


\section{Pendahuluan}

UD. Sumber Alam Buana didirikan pada tahun 1994 oleh Bapak Ahim beralamatkan di Jl. Lundin, Cacalan, Kec. Sukowidi, Banyuwangi. Awal mula berdirinya perusahaan ini adalah ketika pemilik usaha ini mendapat sebuah inspirasi dari seorang wirausahawan oleh-oleh khas Banyuwangi yang mendorong beliau untuk melakukan bisnis serupa khususnya pada pengelohan sale pisang sale. Hal inilah, yang kemudian dimanfaatkan beliau sebagai peluang dengan melihat begitu banyaknya komoditi buah pisang yang belum dimanfaatkan secara maksimal.

Guna kelancaran dan keaslian dalam menjalankan usahanya, perusahaan ini melakukan pendaftaran produk rumah tangga dengan menggunakan PIRT (Produk Industri Rumah Tangga) yang didapatkan melalui Dinas Kesehatan sebagai surat izin skala rumahan yang nantinya usaha tersebut mendapatkan nomor PIRT seperti P-IRT 214351001 019221 yang dimiliki UD. Sumber Alam Buana.

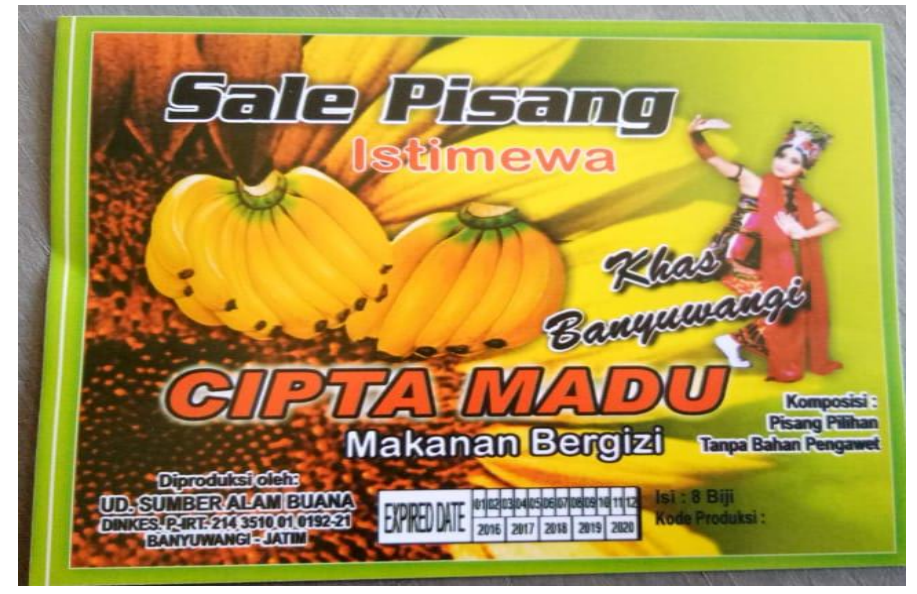

Gambar 1. Label Produk UD. Sumber Alam Buana (Sumber: UD. Sumber Alam Buana, 2019)

UMKM Sale Pisang UD. Sumber Alam Buana merupakan perusahaan skal menengah. Dalam kegiatan produksinya sebagian besar menggunakan 
tenaga manusia. Penggunaan tenaga manusia hanya dilakukan dengan menghaluskan atau meratakan dengan alat besi serta pengirisan sale pisangnya dengan menggunakan pisau mulai dari pangkal ujung atas sampai bawah supaya ketebalannya sama. Sehingga ada kekawatiran bahwa suatu saat nanti usaha kripik pisang ini akan berhenti berproduksi atau bahkan gulung tikar karena tidak mampu bersaing. Hingga kini jumlah karyawan UMKM Sale Pisang ini yang ada 4 orang yang terdiri dari bagian produksi,penggilingan dan pengemasan.

Dilihat dari sisi manajemen, usaha sale pisang masih dikelola secara sederhana (secara perorangan) dimana proses produksi yaitu tahap penjemuran pisang yang telah dirajang belum menggunakan mesin produksi hanya mengandalkan sinar matahari, sehingga produk yang dihasilkan kurang memadai dari sisi kuantitas dan kualitas terutama ketika musim penghujan. Faktor cuaca sangat berpengaruh terhadap produksi rumahannya tersebut. Pasalnya untuk menghasilkan sale yang berkualitas membutuhkan waktu penjemuran selama dua hari. Tapi kalau musim hujan membutuhkan waktu empat hari. Selain itu perajangan pisang hanya menggunakan pisau sederhana sehingga menghasilkan sale dengan ketebalan yang berbeda-beda dan kapasitas produksinya juga relatif rendah. Kondisi produksi sale pisang dapat di jelaskan sebagai berikut:

a. Sale pisang dibuat dengan cara tradisional yaitu dengan cara dirajang secara manual. Dalam kegiatan produksinya sebagian besar menggunakan tenaga manusia. Penggunaan tenaga manusia hanya dilakukan dengan menghaluskan atau meratakan dengan alat besi serta pengirisan sale pisangnya dengan menggunakan pisau mulai dari pangkal ujung atas sampai bawah supaya ketebalannya sama.

b. Kapasitas rata-rata produksi yang dihasilkan selama satu bulan bisa mencapai 1000 unit dengan omset penjualan mencapai $\mathrm{Rp}$ $4.000 .000 /$ bulan 
c. Pencatatan akuntansinya masih dilakukan sangat Sederhana dan tidak adanya kartu persediaan padahal hal ini sangat diperlukan dalam mengelola dan mengadakan persediaan bahan baku maupun barang yang sudah diproduksi agar terciptanya efektifitas dan efisiennya kegiatan operasional

\section{Metode}

Dengan banyaknya produk makanan ringan sekarang ini pemasaran agak mengalami kelesuan sehingga perlu peningkatan kualitas produk dan manajemen untuk mengatasi kelesuan pasar. Wilayah pemasarannya tidak hanya di kabupaten Banyuwangi namun sudah mulai merambah ke kota lain seperti Jember, Bali, Malang dan Surabaya. UMKM ini memiliki target ingin memperluas pemasaran usahanya sampai ke Jawa tengah, Jawa Barat, dan di luar pulau Jawa bahkan di pasar internasional. Namun, konsep usaha toko online belum dipahami secara baik sehingga lebih menekankan pada aktivitas usaha offline saja yang dirasa kurang efektif dan efisien.

Pada saat tim pengusul PKM melakukan kunjungan dengan beberapa pemilik dan melihat situasi sesungguhnya maka tim pengusul PKM dan mitra (dalam hal ini UMKM Sale Pisang UD Sumber Alam Buana) menyepakati permasalahan yang dapat diajukan dalam kegiatan pengabdian masyarakat ini yaitu difokuskan pada pembenahan mekanisasi proses produksi dan metode pemasaran yang berbasis IPTEK yang tepat guna untuk meningkatkan omset penjualan maupun untuk memperluas pangsa pasar.

Menurut hasil analisis situasi teridentifikasi permasalahan utama yang terkait dengan rendahnya kapasitas produksi dan kualitas produk yang perlu ditingkatkan. Produksi sale pisang ini dibuat secara tradisional dengan proses pembuatannya dengan cara mengupas buah pisang terlebih dahulu, 


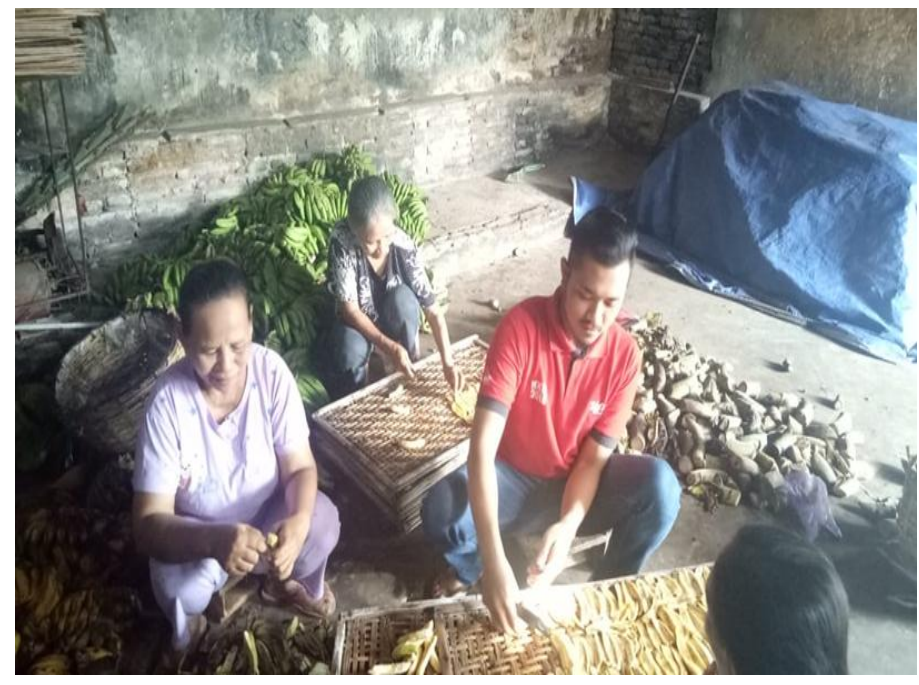

Gambar 2. Proses Penyusunan Buah Pisang (Sumber: UD. Sumber Alam Buana, 2019)

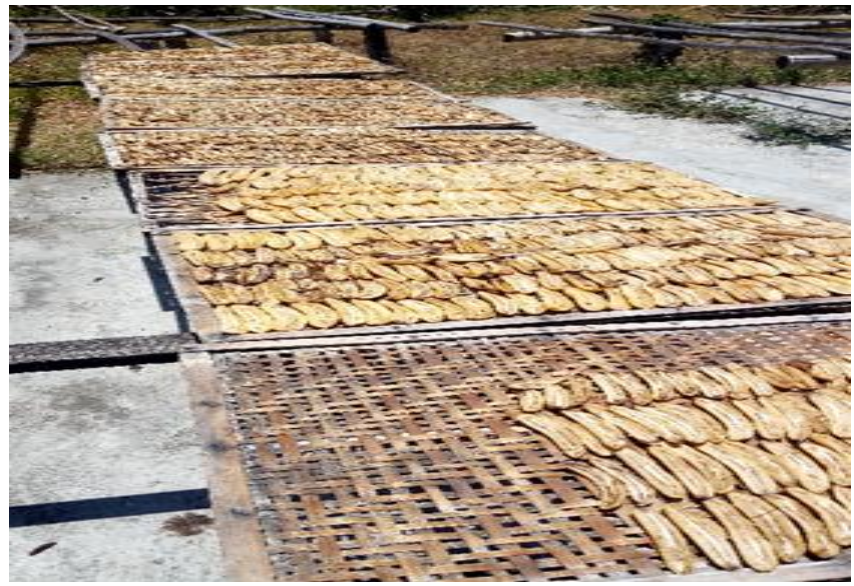

Gambar 3. Proses Penjemuran pisang yang sudah dirajang (Sumber: UD. Sumber Alam Buana, 2019)

Pengirisan sale pisangnya dengan menggunakan pisau mulai dari pangkal ujung atas sampai bawah supaya ketebalannya sama dan dibelah menjadi 2 bagian, kemudian pisang yang sudah dibelah akan ditata diatas nampan yang kemudian dijemur sampai dengan 4 hari sambil membolak balik pisang tersebut. Selanjutnya ditata dan diratakan dengan silinder besi, setelah semua tahap awal selesai maka yang dilakukan adalah pengemasan 
dengan pemberian label. Kemudian sale pisang yang sudah dikemasi dimasukkan didalam kardus untuk untuk dipasarkan.

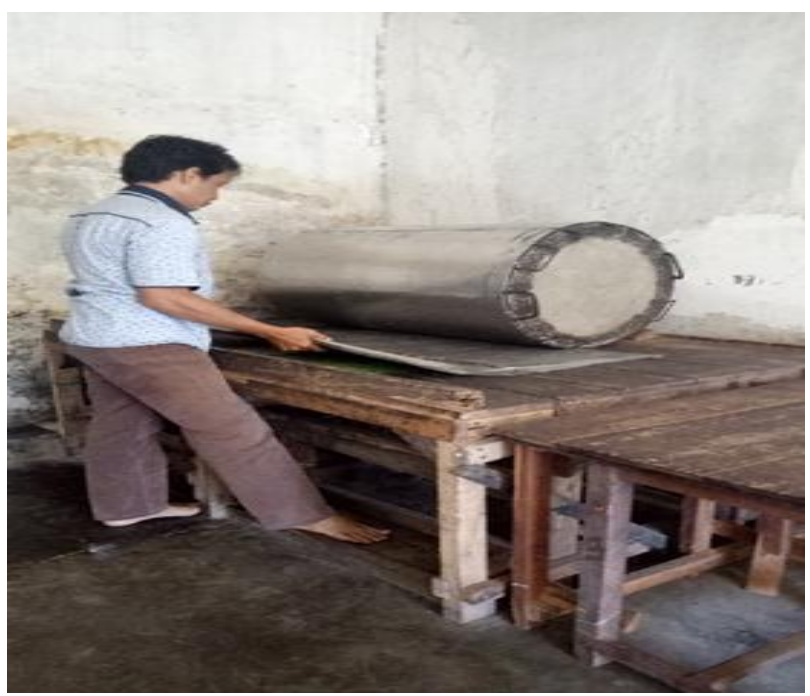

Gambar 4. Proses Silinder Besi dan pengirisan (Sumber: UD. Sumber Alam Buana, 2019)

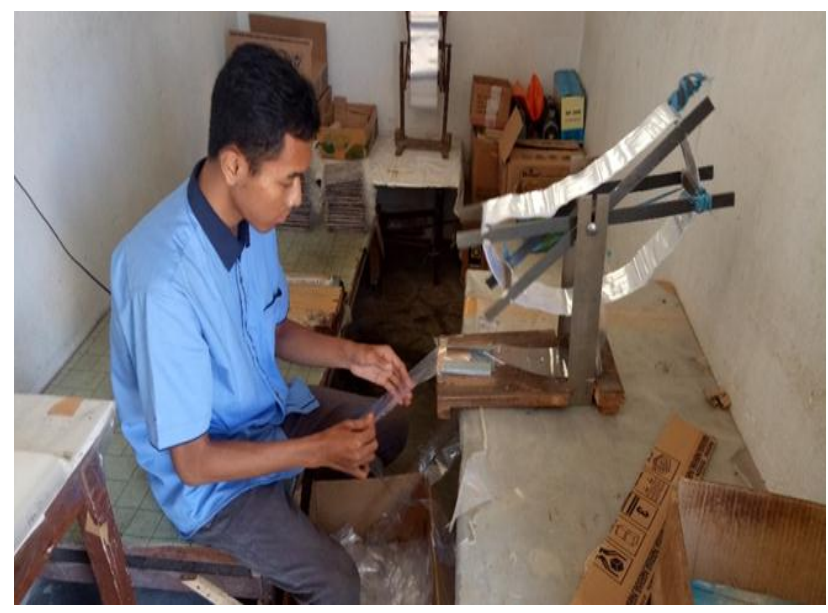

Gambar 5. Pengemasan dan Pemberian Label Produk (Sumber: UD. Sumber Alam Buana, 2019)

Sedangkan yang menjadi kendala aspek kualitas ukuran dan ketebalan pisang tidak sama dan produktifitas yang kurang efisien dan terbatas karena pemotongan dan perajangan menggunakan alat pemotong biasa. Selain itu 
pada pencatatan akuntansinya masih dilakukan sangat sederhana terutama dalam hal pencatatan barang persediaan yang masuk dan keluar

UD. Sumber Alam Buana yang kegiatan usahanya menghasilkan produk makanan berupa sale pisang untuk memenuhi kebutuhan konsumen tentu tidak lepas dengan berbagai kendala selama pemasaran sale pisang. kendala yang sering terjadi di UD. Sumber Alam Buana antara lain:

a. Kurangnya pengetahuan terkait Marketing Mix

b. Ketergantungan dengan musiman yang berakibat tidak ramainya konsumen

c. Perencanaan strategi pemasaran yang belum maksimal

Sebenarnya UD.Sumber Alam Buana memiliki target ingin memperluas pemasaran usahanya sampai ke Jawa tengah, Jawa Barat, dan di luar pulau Jawa bahkan di pasar internasional. Namun, konsep usaha toko online belum dipahami secara baik sehingga lebih menekankan pada aktivitas usaha offline saja yang dirasa kurang efektif dan efisien. Sebenarnya pemilik dan karyawan memiliki telepon seluler berbasis Android belum menguasai teknologi secara tepat guna sehingga menghambat pemasaran produk.

\section{Hasil Dan Diskusi}

Hasil yang dicapai dalam pelaksanaan program pengabdian kepada masyarakat ini mendasarkan pada target dan luaran ditetapkan sebelumnya. Dengan mendasarkan pada target yang luaran yang dicapai, maka hasil yang dicapai dalam pelaksanaan pengabdian adalah sebagai berikut:

\section{Masalah Bidang Produksi}

Berdasarkan permasalahan di bidang produksi yang akan dilakukan dalam Program Kemitraan Masyarakat ini: 
a. Untuk mengatasi rendahnya kapasitas produksi maupun ukuran dan ketebalan pisang yang tidak sama karena mitra menggunakan pisau biasa ,maka tim PKM mengupayakan menyediakan alat perajang pisang sederhana yang bisa dioperasikan secara manual dan melakukan penyuluhan mengenai kegunaan dan pentingnya alat ini. Alat perajang manual ini terbuat dari kayu dan tidak membutuhkan daya listrik sehingga hemat energi. Untuk hasil pemotongan bahan baku pisang sale dapat digunakan memanjang.

b. Setelah diadakan penyuluhan dan penyerahan alat tersebut kepada mitra maka mitra bisa meningkatkan produktifitas bahan baku pisang dengan ukuran dan ketebalan yang seragam juga lebih efektif dari segi waktu penyiapan bahan baku.

c. Berikut ini gambar mengenai pemilihan bahan baku:

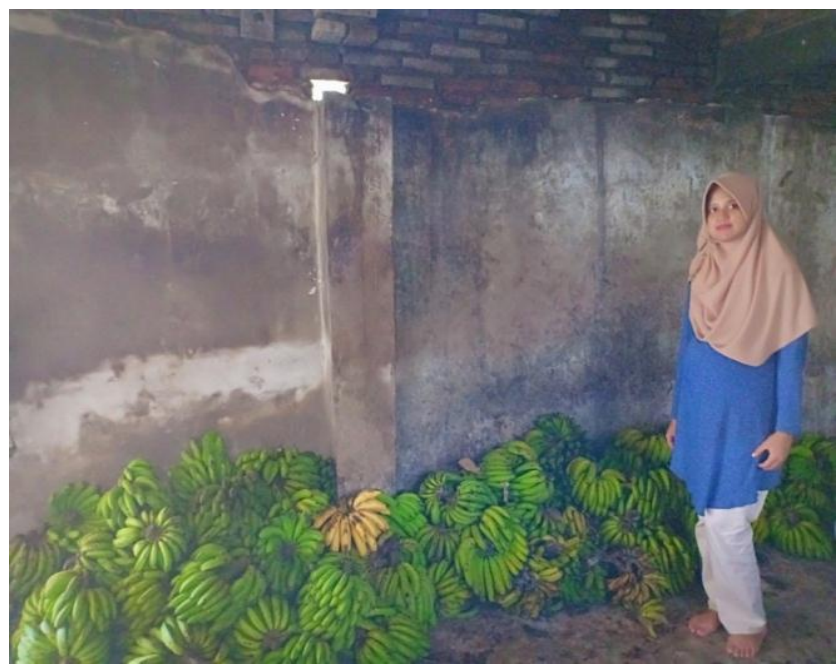

\section{Gambar 6. Bahan Baku Pisang Sale Yang Berasal Dari Pisang Ambon Yang Berkualitas (Sumber: Dokumentasi, 2019)}


d. Tim Program Kemitraan Masyarakat (PKM) melakukan pelatihan perajangan seperti gambar dibawah ini:

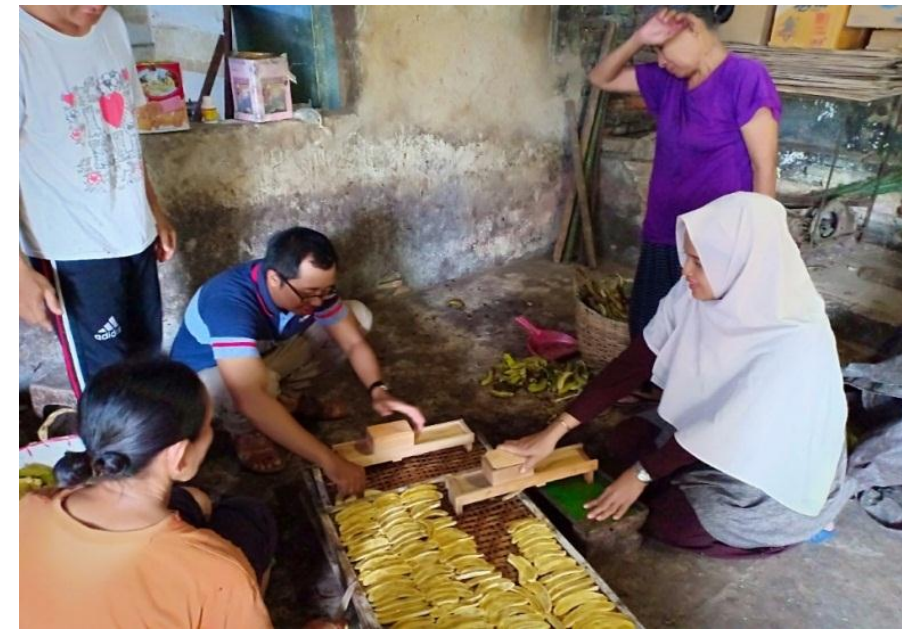

Gambar 7. Pelatihan Perajangan Menggunakan Alat Perajang Pisang Manual (Sumber: Dokumentasi, 2019)

Proses penjemuran sale pisang dapat dilihat sebagai berikut:

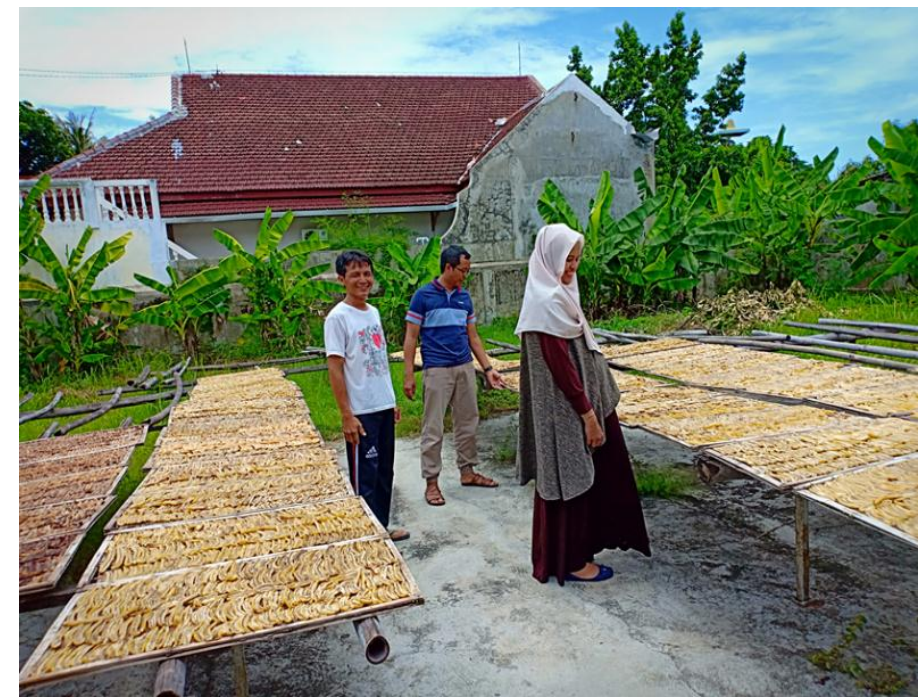

Gambar 8. Penjemuran Bahan Baku Sale Pisang Yang Telah Dirajang (Sumber: Dokumentasi, 2019) 
Mengenai permasalahan pencatatan bahan baku pisang tim Program Kemitraan Masyarakat melakukan sebagai berikut:

Tim Program Kemitraan Masyarakat (PKM) menganalisa Pada UMKM Sale pisang UD. Sumber Alam Buana masih belum menerapkan Metode Persediaan, karena pencatatan akuntansinya dilakukan masih sederhana dan tidak adanya kartu persediaan. Mengingat persediaan merupakan salah satu kunci terpenting dalam operasional usaha hal ini senada dengan pendapat Rangkuti (2014) mendefinisikan "Persediaan bahan baku mempunyai kedudukan yang penting dalam perusahaan karena persediaan bahan baku sangat besar pengaruhnya terhadap kelancaran proses produksi." Maka dalam kegiatan Program Kemitraan Masyarakat (PKM) ini kami mengadakan pelatihan dan pendampingan kepada pemilik dan karyawan yang berkaitan dengan metode persediaan bahan baku dan barang jadi agar pembukuan maupun pencatatan laporan keuangan lebih tertata. ${ }^{1}$

Dengan memilih sistem Metode Perpetual average (rata-rata) pencatatan keluar masuk barang akan dicatat secara kontinuitas dan terus menerus dengan harga beli dirata-ratakan setiap melakukan pembelian sehingga mengetahui secara rinci stok bahan baku.

Sistem pencatatan dengan metode buku (perpetual) ditegaskan Metode perpetual adalah sistem yang mencatat setiap persediaan yang keluar dan masuk ke dalam buku catatan. Tiap jenis barangnya dibukukan menjadi sistem kartu persediaan dan pada pencatatan dalam pembukuan menggunakan rekening pembantu persediaan." Kartu persediaan digunakan untuk mencatat transaksi setiap jenis persediaan,memuat nama barang, tempat penyimpanan barang,kode barang dan kolom - kolom yang dipakai

1 Freddy, Rangkuti. Manajemen Persediaan Aplikasi di Bidang Bisnis.Jakarta: PT Rajagrafindo Persada, 2014. 
untuk mencatat transaksi adalah tanggal pembelian (pemasukan),penjualan dan saldo persediaan. ${ }^{2}$

Pencatatan kartu stok persediaan barang dagangan ini dibuat untuk membantu mitra mengendalikan dan melakukan pengawasan terhadap barang dagangan yang dimiliki mitra dalam usaha UMKM sale pisang. Kegiatan dilakukan dengan cara pendampingan dengan melakukan perbaikan-perbaikan terhadap manajemen dan pengelolaan keuangan kususnya persediaan bahan baku pada pemilik UMKM sale pisang UD. Sumber Alam Buana.

Mengenai pencatatan akuntansi kususnya persediaan kartu stok metode perpetual rata-rata Pada UMKM sale pisang UD. Sumber Alam Buana, mengenai perhitungannya adalah sebagai berikut:

a. Modal awal Rp 2.500.000 memperoleh $120 \mathrm{Kg}$ bahan baku pisang dengan harga per Kg Rp. 20.833.

b. Pada saat saat produksi Sale pisang $1 \mathrm{Kg}$ menghasilkan 40 buah.

c. Maka harga perbuah, harga per Kg Rp. 20.833 : 40 buah = Rp.520 per buah

Jadi : 1 bungkus kemasan isi 8 buah dan 16 buah

Dengan diperoleh Harga Pokok Penjualan (HPP):

Rp.520 Per buah x 8 buah = Rp. 4.160. Dan di jual pada konsumen dengan Harga Rp. 8.000 kemasan isi 8 buah. Apabila 1 bungkus kemasan isi 16 buah x Rp.520 : Rp8.320, Mitra menjual dengan 2 kali lipat harga Pokok Penjuakan (HPP). Berikut ini kemasan Sale Pisang dari UMKM UD Sumber Alam Buana dapat dilihat pada gambar di bawah ini:

2 Baridwan,Zaki. Sistem Akuntansi Penyusunan Prosedur dan Metode.Yogyakarta: YKPN, 2007: 150 


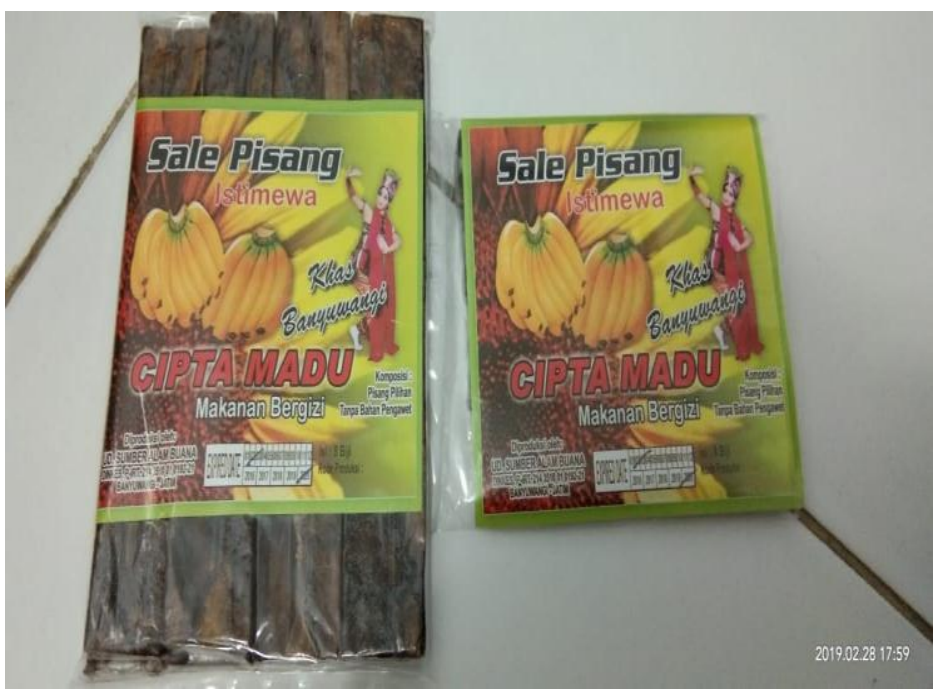

\section{Gambar 9. Produk Pisang Sale UMKM UD Sumber Alam Buana Kemasan}

8 Buah dan 4 Buah (Sumber: Dokumentasi, 2019)

Adapun tim Program Kemitraan Masyarakat (PKM) melakukan pelatihan dan pendampingan pencatatan kartu stok persediaan pada gambar dibawah ini:

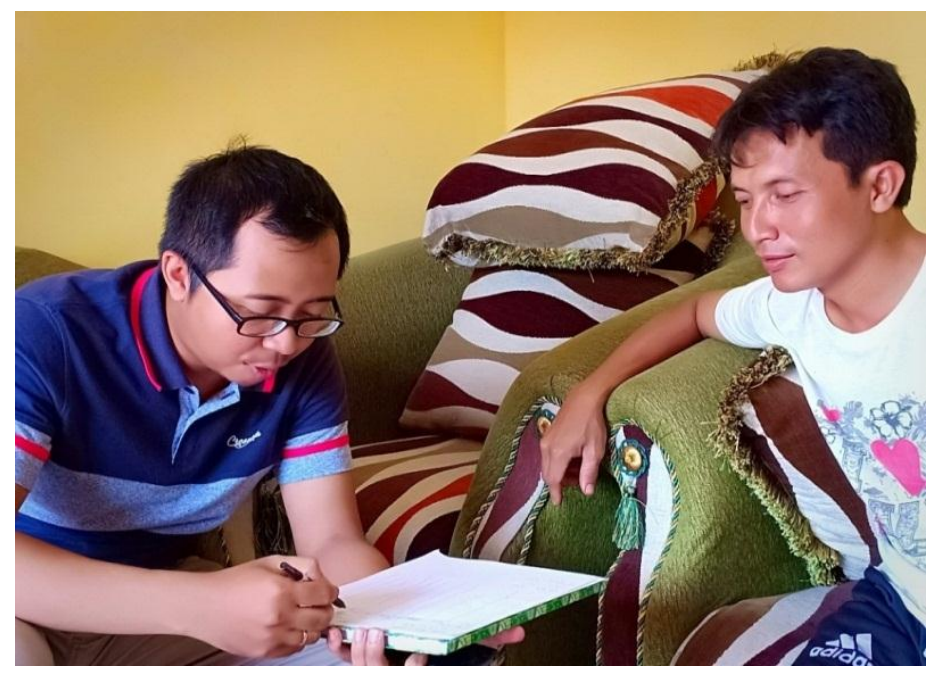

Gambar 10. Pelatihan Pencatatan kartu stok Dengan Metode Perpetual (Sumber: Dokumentasi, 2019) 


\section{Masalah Bidang Pemasaran}

Untuk membantu mitra dalam usaha pemasaran maka kegiatan yang dilakukan tim PKM dalam bidang pemasaran meliputi:

a. Pelatihan pembuatan toko online

Toko online sebagai tempat terjadinya aktivitas perdagangan atau jual beli barang yang terhubung dengan jaringan internet diharapkan dapat memperluas pangsa pasar untuk dikenal dan dapat menambah potensi penghasilan yang lebih besar karena pembeli dapat mengunjungi toko online kapan saja dan membeli produk yang tersedia dalam media internet. Selain itu penjual tidak perlu menimbun stok dan dapat menghemat tenaga karena tidak perlu menjaga barang setiap waktu. Dengan adanya perluasan jaringan pemasaran melalui toko online, konsumen dan pelanggan sale pisang dapat lebih cepat bertransaksi karena sebelumnya untuk membeli pisang sale UMKM ini pelanggan di kota Banyuwangi membeli di toko pusat oleh-oleh Sherly, Ardial, Roxy.

Strategi penjualan melalui toko online ini perlu dicoba oleh produsen atau pemilik UMKM Sale Pisang UD Sumber Alam Buana,sebagai penjual produk sale pisang basahnya yang berkualitas. Sale pisang merupakan makanan yang terbuat dari bahan utama buah pisang yang manis yang sudah dikeringkan sehingga rasanya manis dan legit. Keunggulan dari pisang sale UMKM ini adalah kualitas nya yang baik karena berasal dari bahan baku pisang ambon yang baik. Kualitas pisang sale yang baik terlihat dari warna, rasa ,bau,kekenyalan dan daya simpannya. Selain itu untuk mengatasi banyaknya pesaing maka diperlukan strategi promosi yang sesuai dengan perkembangan saat ini dimana pengguna telepon seluler berbasis android (smartphone) semakin bertambah banyak.

Dalam pelatihan membuat toko online, peserta yang terdiri dari 
pemilik, dan istri dari pemilik terlebih dahulu diajarkan: a pengertian,manfaat dan beberapa contoh nama toko online yang telah dikenal masyarakat luas. Kemudian peserta diajarkan membuat email sebagai portal untuk mengakses ke beberapa website $e$-commerce yang ada (misalnya: bukalapak, tokopedia, dll) serta untuk membuka toko online gratis melalui media sosial seperti facebook dan instagram.

b. Pengenalan istilah-istilah dan fitur-fitur berbahasa Inggris pada media online.

Dalam pelatihan ini mitra dikenalkan dengan beberapa istilah yang sering digunakan dalam transaksi online antara lain:

Seller = penjual $/$ pemilik online shop

Buyer = pembeli atau konsumen

Customer $=$ pembeli order

Supplier = sebutan untuk orang yang memberikan pasokan barang pada penjual

Reseller = sebutan untuk penjual yang menjualkan barang orang lain untuk konsumennya. Dalam istilah sederhananya adalah calo

Dropship $=$ pengiriman barang kepada konsumen dengan mengatasnamakan pihak kedua selaku reseller

TF $\quad=$ transfer

Refund $=$ transaksi dibatalkan,barang dikembalikan kepada penjual dan uang dikembalikan kepada pembeli

Reject $=$ barang tidak dalam kondisi baik,ada cacat

Ready stock $=$ barang tersedia

Po $=$ singkatan dari Pre Order. Ini adalah sistem yang banyak dipakai oleh mereka yang menjual barang impor,atau custom.Jadi,barang baru akan dipesankan atau diproduksi setelah jadwal PO berakhir,dan dikirim setelah barang jadi. 
Restock = barang yang diperjualbelikan tersedia kembali,setelah mengalami out of stock

Out of stock = keadaan barang yang habis persediaanya di tangan penjual atau supplier

Sold $\quad=$ habis terjual

Trusted = terpecaya, bukan penipu

Testimonial $=$ pesan dan kesan dari pelanggan.Ini biasanya dijadikan bukti untuk meyakinkan pembeli lainnya berdasarkan pengakuan pembeli sebelumnya

DP $($ Down Payment) = sistem pembayaran yang tidak langsung dibayar lunas. Sistem pembayaran ini biasanya digunakan untuk barang dengan sistem pre order

Full payment $=$ pembayaran penuh,atau langsung

Booked $=$ produk telah dipesan oleh orang lain.

Keep = Hampir sama dengan booked diatas,keep biasanya dilakukan oleh pembeli yang sudah pasti akan membeli satu produk tapi belum sempat melakukan pembayaran. Pesanan keep terlebih dahulu agar tidak terjual kepada orang lain.

Hit and run = Istilah untuk mereka yang memesan barang dan janji mau bayar tanggal sekian tapi tidak menepatinya.

Ongkir/ shipping cost (ongkos kirim)= biaya pengiriman dari tempat penjual ke pembeli

Rekber $=$ singkatan dari rekening Bersama. Maksudnya ini adalah rekening pihak ke -3 yang menjadi mediator antara penjual dan pembeli

Resi $=$ nomor bukti pengiriman barang yang didapatkan dari pihak ekspedisi

COD (Cash on Delivery $)=$ cara pembelian dimana penjual dan pembelinya bisa bertatap muka. Bisa janjian di sebuah tempat,atau penjual 
anterin ke rumah pembeli. Pembayaran di lakukan saat mereka saling bertemu. ${ }^{3}$

Sedangkan fitur berbahasa Inggris yang terdapat pada media online,meliputi:

Paid promote yaitu membayar sejumlah uang kepada account media sosial untuk mengiklankan online shop.

Hastag promote yaitu memberi caption dengan kata-kata yang menjual dengan ditandai symbol hastag (\#) di tiap foto, misalkan \#jualmakanan\#jual minuman\#fashion sehingga pembeli dengan mudah menemukan apa yang mereka cari lewat hastag

Endorse yaitu memberikan produk kepada selebriti media untuk diiklankan.

Jam pick up adalah waktu bagi konsumen untuk bisa memesan

Start order adalah saat konsumen bisa mulai memesan

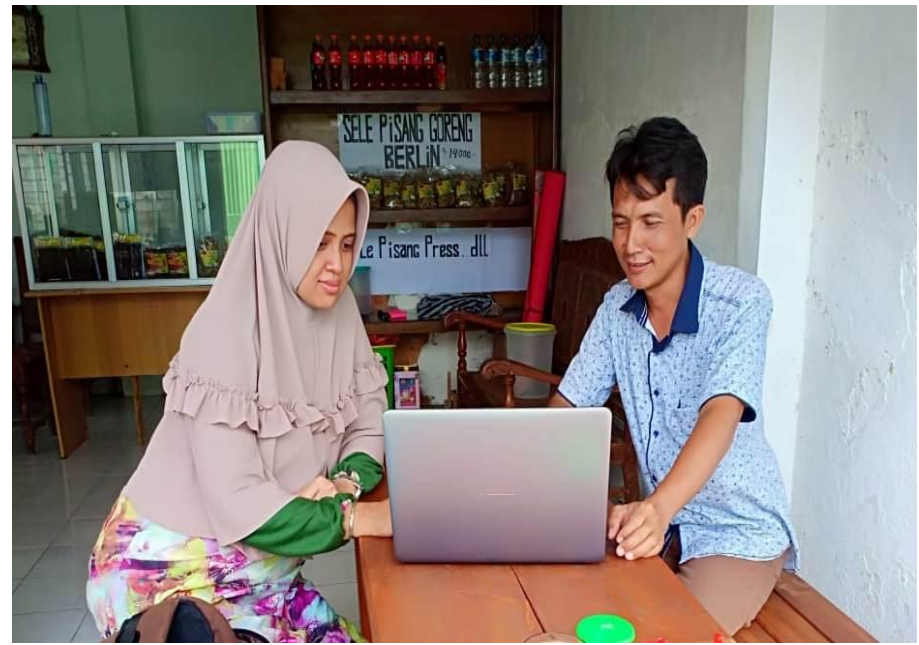

\section{Gambar 11 Kegiatan Pelatihan Pemasaran toko online Tim bersama Mitra (Sumber: Dokumentasi, 2019)}

Dibawah ini dilakukan tim PKM dalam menerapkan aplikasi pemasaran

${ }^{3}$ Sumber: https//www.onlino.web.id/2014/09/27-istilah-dalam-jual-beli-online.html 
online melalui media sosial (facebook) dan menerapkan market place:

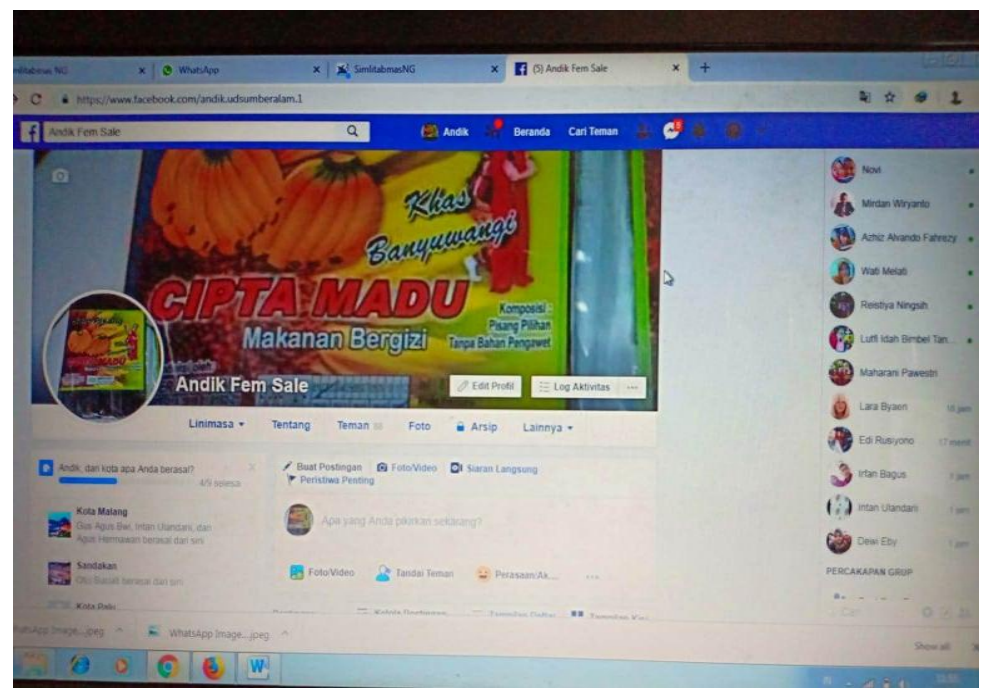

Gambar 12. Aplikasi yang diterapkan untuk menunjang pemasaran Sale Pisang (Sumber: Dokumentasi, 2019)

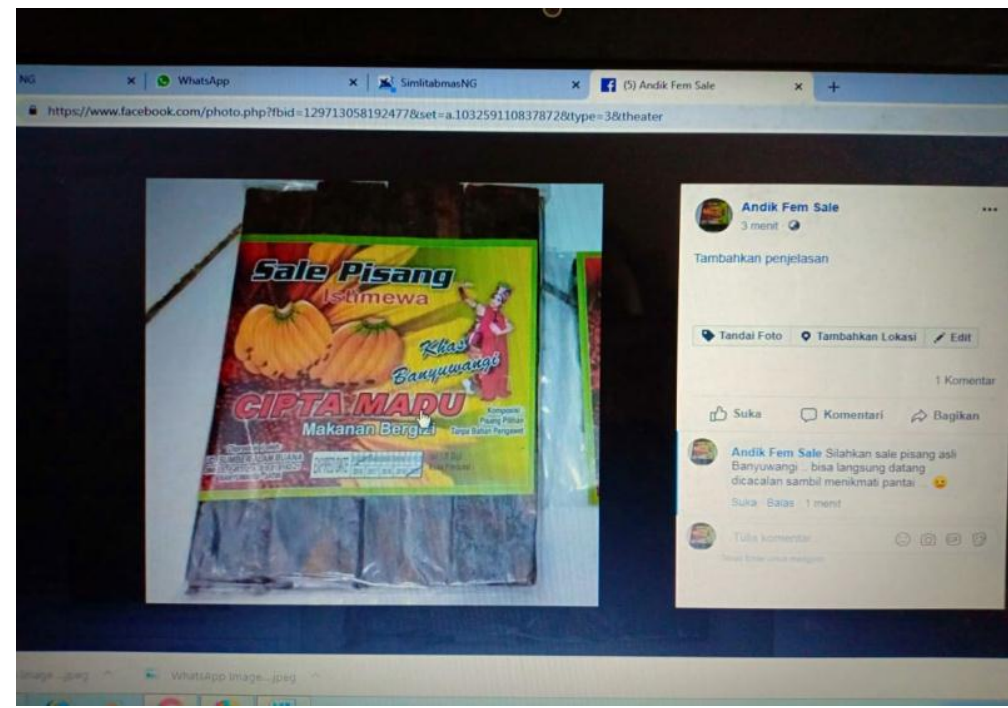

\section{Gambar 13. Pemasaran Sale Pisang menggunakan Media Sosial} (facebook) (Sumber: Dokumentasi, 2019) 
c. Penyediaan etalase dari kaca berbentuk rak untuk memajang produk UMKM tersebut yang berupa sale pisang basah didepan tempat produksinya. Karena ukurannya yang tidak terlalu besar yaitu $120 \mathrm{~cm} \mathrm{X}$ $60 \mathrm{~cm} \times 40 \mathrm{~cm}$, etalase ini dapat juga dibawa ketika pemilik UMKM ini mengikuti pameran produk atau berjualan di Pantai Cacalan pada hari libur. Gambar dibawah ini etalase kaca yang telah diterima mitra:
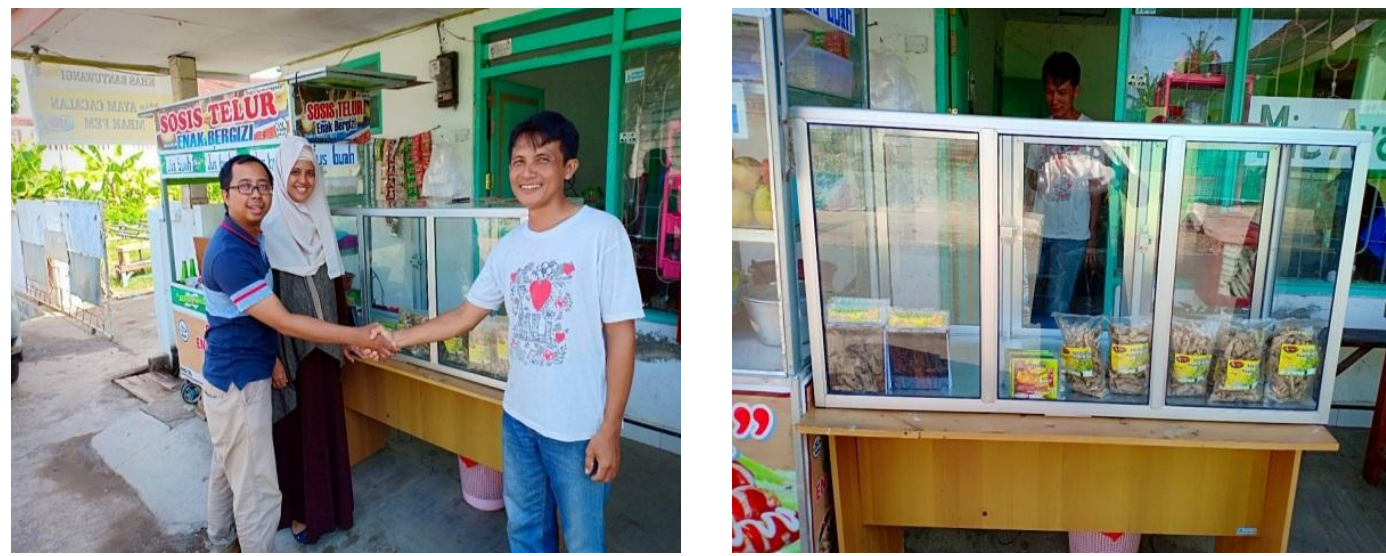

Gambar 14. Tim Program Kemitraan Masyarakat (PKM) Penyerahan etalase kaca kepada mitra Untuk Mendisplay Produk Sale Pisang UMKM UD Sumber Alam Buana (Sumber: Dokumentasi, 2019)
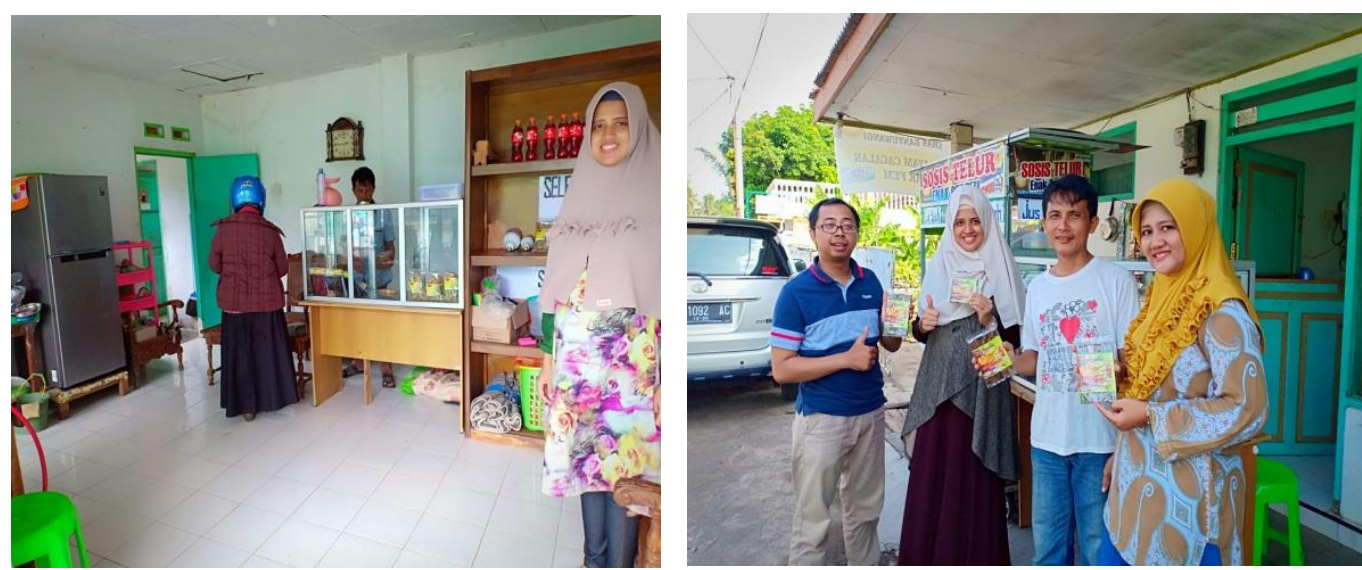

Gambar 15. Transaksi Penjualan Konsumen Merasa Puas Dengan Adanya Display Produk Sale Pisang Isi 8 Buah Dengan Harga Rp.8.000

(Sumber: Dokumentasi, 2019)

Peningkatan Produksi, Pencatatan Kartu Persediaan Dan Pemasaran Sale Pisang 
Dengan adanya etalese membantu mitra untuk memasarkan hasil sale pisang yang dikelola dan konsumen merasa puas dengan melihat produk sale pisang. Sale pisang asli produk Banyuwangi menjaga agar selalu tetap ada dan berkembang mengikuti pasar berisi delapan (8) biji dengan harga Rp.8.000 yang siap untuk dikonsumsi.

\section{Simpulan}

Program Pengabdian Kepada Masyarakat (PKM) bertujuan untuk membantu meningkatkan kesejahteraan para penggerak UMKM di Banyuwangi dalam mengelola usahanya salah satunya ditujukan kepada UMKM Sale Pisang UD Sumber Alam Buana yang masih memerlukan pendampingan dalam hal produksi, pengelolaan laporan keuangan dan perluasan jaringan pemasaran. Oleh sebab itu,perlu adanya langkah-langkah penyelesaian masalah sebagai usaha untuk meningkatkan kesejahteraan UMKM ini yaitu:

a. Dalam program Pengabdian Kepada Masyarakat (PKM), UMKM Sale Pisang UD Sumber Alam Buana masih menggunakan pisau pemotong sederhana sehingga kapasitas produksi terbatas. Untuk mengatasi rendahnya kapasitas produksi, tim Pengabdian Kepada Masyarakat (PKM) memberikan penyuluhan pentingnya penggunaan alat yang lebih praktis dalam merajang pisang serta memperlihatkan cara pemakaian alat perajang pisang kepada karyawan UMKM Sale Pisang UD Sumber Alam Buana. Dengan adanya alat perajang pisang kapasitas produksi meningkat dan membantu mitra sehingga lebih efektif dan efisien.

b. Pencatatan sederhana yang dilakukan mitra dalam mengendalikan siklus persediaan bahan baku dan barang jadi sebelumnya kurang memberikan data yang tepat, maka Tim Pengabdian Kepada Masyarakat (PKM) mengadakan pelatihan dan pendampingan kepada pemilik dan karyawan yang berkaitan dengan pencatatan kartu stok dengan metode perpetual 
persediaan bahan baku dan barang jadi yang telah diterapkan menghasilkan pembukuan maupun pencatatan laporan keuangan lebih tertata dan dipahami.

c. Untuk mengatasi permasalahan pemasaran Mitra UMKM Sale Pisang UD Sumber Alam Buana maka Tim Pengabdian Kepada Masyarakat (PKM) mengadakan pelatihan membuat toko online media sosial maupun email dan melakukan pengenalan istilah-istilah baik fitur-fitur berbahasa Inggris untuk bertransaksi pada media online kepada pemilik maupun karyawan

d. Sedangkan untuk memajang hasil produk UMKM berupa sale pisang basah di tempat produksi maka tim Pengabdian Kepada Masyarakat (PKM) menyediakan etalase dari kaca berbentuk rak dengan tujuan menarik konsumen serta meningkatkan penjualan baik secara online atau offline.

\section{Daftar Referensi}

Baridwan, Zaki. 2007. Sistem Akuntansi Penyusunan Prosedur dan Metode.Yogyakarta: YKPN

Chaffey.D.2011.E Business Commerce Management: Strategi. Implemention. and Practice (5 $\left.5^{\text {th }}\right)$.New Jersey: Person Education.

Endriastuti,Annysa.dkk Pelatihan Pemasaran,Pemberdayaan Toko Online. Dan Pengenalan m-Commerce Pada Produk Unggulan Jagung Tortila di Kecamatan Trucuk Kabupaten Bojonegoro.Jurnal Pengabdian Masyarakat Universitas Airlangga volume 1 no 2 Tahun 2018

Freddy, Rangkuti. 2014. Manajemen Persediaan Aplikasi di Bidang Bisnis.Jakarta: PT Rajagrafindo Persada

Profil UMKM UD. Sumber Alam Buana Sumber: https//www.onlino.web.id/2014/09/27-istilah-dalam-jual-belionline.html. 